\title{
Universal Model of Organizational System
}

\author{
Bogdan ĆWIK \\ Military University of Technology in Warsaw, Warsaw, Poland \\ bogdan.cwik@wat.edu.pl
}

Received date:6 September 2019; Accepted date:21 November 2019; Published date: 2 March 2021

Academic Editor: Nataliia Gennadievna Fersman

Copyright (C) 2021. Bogdan ĆWIK. Distributed under Creative Commons Attribution 4.0 International CC-BY 4.0

\begin{abstract}
The basic premise of the article is that the reality surrounding all systems has been constituted by collections of various organizations that interact in various forms. These organizations change, evolve, develop and often fail. A feature of modern reality is the one that the organizations which create it, function in non-deterministic situations, mainly in risky or uncertain situations. Hence, in numerous works of modern researchers, the terms "world of threats", "society of risk" and "world community of dangers", are found. There is a growing need for the development of different security systems, including the development of threat monitoring systems. The essence of these systems is the need to anticipate the development of the situation in order to take preventive measures in time. The paper presents the concept of a universal unit of reality, which is a theoretical and logical construct, based mainly on Ludwig von Bertalanffy's general system theory and Karl R. Popper's evolutionary epistemology. This unit has been given a working name of an organisational system model. The basic elements of such a unit, its structure and relations have been identified, and the principle of its functioning has been indicated. This principle expresses the logic of the development and functioning of such a unit. It is assumed that with the help of the developed model, hypothetical deductive reasoning or anticipation of the causes of occurring phenomena, as well as the mechanisms of events occurring in the turbulent environment of a modern organisation will be possible, allowing for more effective management of this organisation. The verification was made on the basis of the observation of actual organizational behavior. The concepts of three models were presented and discussed, providing verifying examples.
\end{abstract}

Keywords: Organisational System, Threat Perception, Organisational System Development, Quantitative Development of An Organisation, Qualitative Development of An Organisation.

\section{Introduction}

\section{Background}

Contemporary organizations (enterprises, foundations, associations, offices and institutions) are forced to operate in a turbulent environment, adapt to these conditions and carry out their tasks in them, and at the same time, in accordance with the principles of energy conservation, they have an impact on this environment, marking their participation in further development and already excessive turbulence (Makridakis,

Cite this Article as: Bogdan ĆWIK (2021)," Universal Model of Organizational System", The Journal of Organizational Management Studies, Vol. 2021 (2021), Article ID 341084, DOI: 10.5171/2021.341084 
Taleb, 2009). Employees carrying out their tasks must, in such conditions, dynamically shape relations with the environment, not only react to the situations and rely on the information provided, but must also search for it and process it themselves. Managers as well as employees of organisations face the task of assessing situations and issuing judgements in conditions where various, variable and unknown economic, social and psychological impacts may occur at any time. At the same time, they are under pressure to make quick and accurate assessments, being aware that any mistake can cause costly results.

Interpretation and models concerning the traditional organization (Ander-son, Arrow, \& Pines, 1988; Bailey, 1994; Buckley, 1968; Checkland, 1981; For-rester, 1968 and Von Bertalanffy, 1973) seem to be outdated now. Besides, the systematic review of modern organizations (Cornell \& Jude, 2015; Lock, 2019, and Taylor, Suminski, Das, Paxton \& Craig, 2018) underlines the net-working and collaboration more than ever before, as well as growing dynamics and complexity. Apart from that, the systemic approach indicated by these authors focuses mainly on pointing relationships and holistic views as well as on the synergy effect between cooperated elements of systems, which at the moment, also seems to be insufficient.

It seems necessary to develop a modified approach when analyzing the modern organization - taking into account development mechanisms, allowing anticipation of changes in conditions of uncertainty, as well as anticipating possible directions of adaptation in response to changing or new conditions in the external environment.

Descriptions of the environment of modern organizations are dominated by statements about turbulence, uncertainty, complexity and chaos. At the same time, researchers and experts are expected to seek order, propose solutions, create diagnostic and warning systems, as well as create plans or programs. On the other hand, there is a growing awareness of the growing risk of failure to implement such activities.

\section{Aim}

The purpose of the article is to present a model of a universal organisation, ensuring a rational and effective perception of the situation in turbulent conditions. The assumption is that this model will be useful in various areas of reality constituting the external and internal environment of a modern organization (not only economic), which is also general enough to take into account the dynamics, diversity and complexity of this environment.

\section{Methods}

The scientific methods used in the paper include an analysis and a criticism of source materials, a logical analysis and a logical construction, as well as heuristic methods: the "fresh look" method and the analogical transfer method. The methods of deductive reasoning and enumerative induction were incorporated into these methods.

The models presented in this article are the result of the author's own research and theoretical studies in the area of perception processes and cognitive processes in nondeterministic situations.

\section{Organisational System Model}

The model of the universal perception of reality constituting the environment of a modern organisation will be based on the model of the basic element constituting this reality, reflecting the basic characteristics of this reality. These characteristics are: the pursuit of integration, including the creation of comprehensive structures, the pursuit of complexity, the growing dynamics of change and the development towards intangible forms.

A diagram of such a model, which can be identified in any environment (economic, biological, social and physical) is shown in Fig. 1. When creating such an element, the concept of a system was taken into account and understood according to the general system theory of Ludwig von Bertalanffy (Bertalanffy, 1968 and Hofkirchner, Schafranek 2011, pp. 177-194), as a sepa-

Bogdan ĆWIK, The Journal of Organizational Management Studies, DOI: $10.5171 / 2021.341084$ 
rate fragment of reality in the form of a set of components and relations between them, and the concept of an organisation, defined as a whole, which organises internal components for implementing joint actions.

It is assumed that such a unit of reality is called an organizational system, maybe any organization as well as the reality surrounding this organization, which is shaped by the presence of other similar organizational systems. Such systems undertake or are subject to various behaviors on the part of the environment, such as cooperation, struggle and forcing adaptation. As a result, in the case of success, a system undertakes behaviours such as: synergy and emergence, and in the event of failure, it undertakes behaviours such as: fall, degradation and decay.

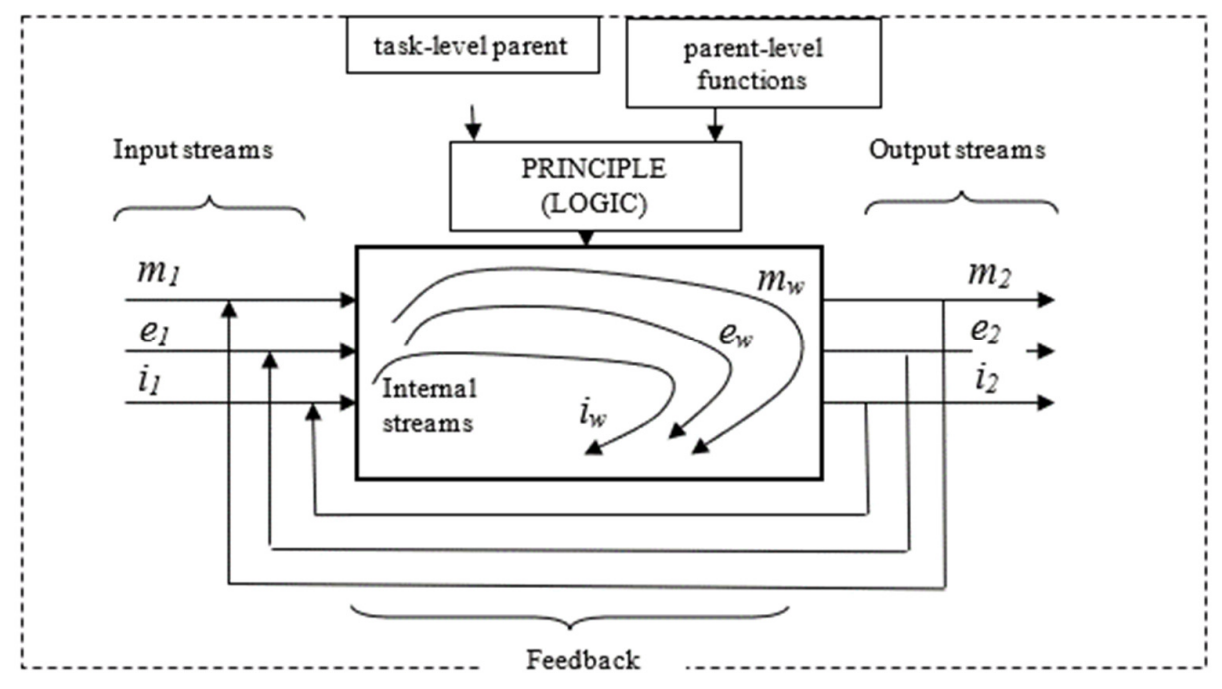

Fig. 1: General diagram of an organisational system

$m_{1}, m_{2}, m_{w}$ - mass streams; $e_{1}, e_{2}, e_{w}$ - energy streams; $i_{1}, i_{2}, i_{w}$ - information streams Source: own work

The model of such a system is an open structure, supported by specific infrastructure, inside which internal and external flows of mass, energy and information streams are organised. The organisation of these flows is not accidental, but follows a specific principle (logic) that permeates all of the model's elements. This principle is refined by the functions and tasks of the higher order level, while imposing, to a certain extent, the tasks and functions for the lower order levels of this model. This is a novelty in relation to previous system interpretations. The model is universal (general) and can be applied to all levels of contemporary reality, i.e. at individual levels of the development of the biological world, as well as in the world of physics, the world of chemistry and social worlds, and also integrate them. The essence of individual streams (in general) can be understood as follows:

Mass stream includes the part of reality that contains mass or has "presence" - on a nano scale, it is the mass of elementary particles; on a micro scale, it is the mass of microparticles (physical and biological); on a macro scale, it is the mass of freight transported by road, the number of products manufactured by the enterprise, the number of cubic metres of gas or tons of crude oil in pipelines, the quantity of goods, or increasingly more often services (intangible products) produced by the enterprise - they flow into and out of the organisational system, they move inside it and may also be transformed;

Energy stream - determines the existence of a movement and starts the flows - starting

Bogdan ĆWIK, The Journal of Organizational Management Studies,

DOI: $10.5171 / 2021.341084$ 
from quantum energy on a nano scale, all forms of energy on a micro scale (mechanical, heat, electric, chemical and biological energy) and various forms of energy on a macro scale (generated in refineries, power plants and heating plants). In addition to the traditional forms of energy, mental energy of a person or a group of people should also be taken into account;

Information stream - determines the control, including the optimisation of mass and energy stream flows, encompassing information on basic processes and auxiliary processes that secure the functioning of the organisational system and its elements. Information can be considered to be of any impact (information is in the form of energy intended for control), which is associat- ed with controlling the course of processes. On a nano scale, it can constitute electrical or mechanical interactions in the form of impacts of moving elementary particles, similarly on a micro scale. At the cell level, information is transferred by sequences of nitrogen bases in DNA. At the organism level, it can be stimuli or sensations perceived by the senses. Further examples include indications of measuring instruments and the content of messages expressed in words in the form of texts or images.

A model of such an organisational system can express the environment and its elements for any organisation and be presented as a set of the following elements:

where:

$$
\mathbf{S O}^{\mathrm{i}}=\left\{\mathbf{M}^{\mathrm{i}}, \mathbf{E}^{\mathrm{i}}, \mathbf{I}^{\mathrm{i}}, \mathbf{Z}^{\mathrm{i}}, \mathbf{M O}^{\mathrm{i}}\right\}
$$

SO $^{i}$ - $i$-th organisational system, whereas:

$\mathbf{S O}^{i} \sqsubset \mathbf{U}$, where $\mathbf{U}$ means the space of organisational systems

$\mathbf{M}^{\mathrm{i}}$ - mass stream (of intangible products) of the $i$-th organisational system,

whereas:

$$
\mathbf{M}^{\mathrm{i}}=\left\{m_{1}, m_{2}, \ldots m_{n}\right\}, \text { where } k=1,2, \ldots, \mathrm{n}
$$

where: $m_{k}-k$-th mass stream.

$\mathbf{E}^{\mathrm{i}}$ - energy stream of the $i$-th organisational system, whereas:

$$
\mathbf{E}^{\mathrm{i}}=\left\{e_{1}, e_{2}, \ldots e_{m}\right\}, \text { where } k=1,2, \ldots, \mathrm{m} \text {; }
$$

where: $e_{k}-k$-th energy stream.

$I^{\mathrm{i}}$ - information stream of the $i$-th organisational system, whereas: $\mathbf{I}^{\mathrm{i}}=\left\{i_{1}, i_{2}, \ldots i_{w}\right\}$, where $k=1,2, \ldots, w$;

where: $i_{k}-k$-th information stream.

Another element of the model is a set of structures of the $i$-th organisational system $\mathbf{Z}^{\mathrm{i}}$.

where:

$$
\mathbf{Z}^{\mathrm{i}}=\left\{\mathbf{S}^{\mathrm{i}}, \mathbf{I N F}, \mathbf{R}^{\mathrm{i}}\right\}
$$

$\mathbf{S}^{\mathrm{i}}$ - set of elements of the structures of the $i$-th organisational system, $\mathbf{S}^{\mathrm{i}}=\left\{s_{1}, s_{2}, \ldots s_{h}\right\}$, where $k=1,2, \ldots, h$

where: $s_{k}-k$-th element of the system's structure.

$$
\begin{aligned}
& \text { INF }^{\mathbf{i}} \text { - set of infrastructure subsystems of the } i \text {-th organisational system } \\
& \text { INF }^{\mathbf{i}}=\left\{\inf f_{1}, \inf _{2}, \ldots \inf f_{s}\right\} \text {, where } k=1,2, \ldots, s
\end{aligned}
$$

Bogdan ĆWIK, The Journal of Organizational Management Studies, DOI: $10.5171 / 2021.341084$ 
where: $i n f_{k}$ - $k$-th infrastructure subsystem;

Organisational systems build or develop infrastructures in their structures to maintain transport, communication and position relationships. Infrastructure often defines the physical boundaries of the system, pro-

tects mass, energy and information stream flows, and consolidates position relationships. Negative impacts can cause significant qualitative changes and lead to an infrastructure degradation.

$\mathbf{R}^{\mathrm{i}}=\left\{\mathbf{R K}^{\mathrm{i}}, \mathbf{R T}^{\mathrm{i}}, \mathbf{R P}^{\mathrm{i}}\right\}$, set of internal relationships of the $i$-th organisational system, where: $\mathbf{R K}^{\mathrm{i}}$ - set of communication relationships of the $i$-th organisational system, $\mathbf{R K}^{\mathrm{i}}=\left\{r k_{1}, r k_{2}, \ldots r k_{v}\right\}$, where $k=1,2, \ldots, v$

where: $r k_{k}$ - $k$-th communication relationship of the system;

Communication channels ensure the flow of information, messages, stimuli and signals. The quantity, quality and activity of these relationships determine the commu- nication potential of the system, which manifests itself in the ability to control the system.

\section{$\mathbf{R T}^{\mathrm{i}}$ - set of transport relationships of the $i$-th organisational system} $\mathbf{R T}^{\mathrm{i}}=\left\{r t_{1}, r t_{2}, \ldots r t_{m}\right\}$, where $k=1,2, \ldots, m$

where: $r t_{k}-k$-th transport relationship;

Transport relationships form a network of transport channels, ensuring mass and energy flow inside the system as well as from the external environment. These types of channels can be seen at every level of the organisational systems: individual atoms, chemical compounds, biological organisms, symbiotic structures, economic structures, social structures as well as other networks of the organisational systems.

$$
\begin{aligned}
& \mathbf{R P}^{\mathrm{i}} \text { - set of position relationships of the } i \text {-th organisational system } \\
& \mathbf{R P}^{\mathrm{i}}=\left\{r p_{1}, r p_{2}, \ldots r p_{p}\right\}, \text { where } k=1,2, \ldots, p \\
& \text { where: } r p_{k}-k \text {-th position relationship; }
\end{aligned}
$$

These relationships determine the mutual position of internal elements of the system in relation to each other.

All of the elements, structures and relationships are determined (are shaped) by a specific logic mentioned form a specific "principle" (logic) that determines the nature of a given organizational system. In an artificial environment, an example of this is cellular automata, i.e. artificial structures in the form of simple computer programs, which entered into the computer's operational memory, having a "principle" encoded inside for connecting others based on colour, shape, etc. and which show activity, move and connect, and the result is the generation of a variety of fractal structures. Stephan Wolfram conducted extensive research on this type of structures (Wolfram, 2002). In the case of a natural organisational system (enterprise, eukaryotic cell and organism), "logic of general optimisation" is the principle, revealing that every action of an organisational system is implemented in such a way that it can be carried out at the lowest possible energy cost. Therefore, in any natural organisational system, a set of mechanisms implementing the logic of optimisation can be identified, marking them as:

MO ${ }^{\text {i }}$ - set of mechanisms optimising the functioning of the $i$-th organisational system, whereas these mechanisms are shaped by the "principle" of optimisation logic and the functions and tasks derived from the higher order level.

\section{Discussion}

According to the logic of common optimization, each organizational system equipped with what was presented above; "princi-

Bogdan ĆWIK, The Journal of Organizational Management Studies, 
ple", organizes its activities in such a way as to carry out all work with the least amount of energy. As a result, a falling stone chooses the shortest path to the ground, water spilled on a slope chooses the path that ensures the least flow loss, the movement of electrons around the nucleus of an atom, or the movement of a planet around a star runs along the most energy-efficient path. In nature, optimisation is widespread and visible in the behaviour of molecules, cells, organisms and societies. Generally speaking, it can be said that every activity is subject to optimisation in an organizational system. All flows are optimised, the structure is optimally created and the infrastructure is optimally built. Here this study can repeat after Kenneth J. Arrow that "everyone strives for optimal organisation" (Arrow, 1971, p. 226) or after Henry Bergson that "each of the species, through which life passes, aims only at its own convenience. It goes to what requires the least effort" (Bergson, 2004, p. 125). Generally speaking, a thesis can be put forward, that the existence and functioning of organizational systems are associated with the existence of the so-called "logic of common optimization", which is the main driving force triggering optimization mechanisms in organizational systems.

Adopting the thesis of the "logic of common optimisation", it can be explained on the basis of deductive reasoning that, based on this logic, the atomic structures of the elements from the Mendeleev table were formed, which in turn created everything that exists in nature, around the enterprise and also in the Universe. As a result of the functioning of the aforementioned "logic", hydrocarbon structures of organic compounds arranged themselves as if they had an encoded tendency towards the rational behaviour, taking the most advantageous positions in the structures they created.

The logic of general optimisation can be seen in the laws of science, including Newton's law of dynamics, the laws of thermodynamics, the laws of fluid flow, as well as the laws of electric current and other scientific laws. The result of the presence of the logic of general optimisation in economic sciences is the "principle of rational man- agement, as well as the emergence of economics itself as a science dealing with the rational allocation of resources. The result of this logic is, among others, the Pareto principle, Occam's Razor, the Deming Cycle and other laws of economic and social sciences. The effect of this logic is also in the theory of research and operations, the theory of optimisation and mathematics (Hopej, 2010 and Radosiński, Tomczak, 2017).

To właśnie logika powszechnej optymalizacji kierunkuje procesy ewolucjne wszelkich systemów organizacyjnych, w tym systemów biologicznych. Wyjaśnia też, wskazane przez G. C. Wiliamsa mechanizmy adaptacji i naturalnej selekcji (Williams, 1992). Interpretując rzeczywistość $\mathrm{Z}$ uwzględnieniem tej logiki, widać też, mechanizmy przetrwania i rozwoju organizmówżywych, w tym mechnizmy objęte koncepcją „sefish gene) Richarda Dawkinsa (Dawkins, 2018).

It is the logic of universal optimization that guides the evolutionary processes of all organizational systems, including biological systems. It also explains the mechanisms of adaptation and natural selection indicated by G. C. Williams (Williams, 1992). By interpreting reality taking this logic into account, the mechanisms of survival and development of living organisms can also bee seen, including mechanisms covered by the concept of the "selfish gene" by Richard Dawkins (Dawkins, 2018).

The "logic of general optimization" is the primary and immanent logic of organizational systems. It is the overriding principle that directs all processes related to the organization of structures and the flow of mass, energy and information. It is the mechanisms resulting from this logic that shape the reality constituting the external environment of a modern enterprise. They impel integration, creating banking networks, commercial networks, distribution networks, supply chains, logistics networks, networks created on the basis of international corporations and others. Thanks to them, the social networks were created, established between people physically, as well as electronically: via the In- 
ternet, on Twitter, Facebook and other Internet objects.

To sum up, it can be said that "the overriding mechanism (logic) shaping the development of behaviour and development (evolution) of each organisational system is organising the flow and processing of mass, energy and information, as well as striving to incur the least energy expenditure in the actions taken." As a result, the natural feature of organisational systems is the creation of ordered structures and increasingly complex forms, which at the same time requires an increasingly complex control. In the course of action, the logic of development is created, mechanisms are launched on the basis of various forces: atomic, chemical, biological, social, economic, psychological and others, and everything is subordinated to a single superior logic - the "logic of general optimisation".

The model of an organisational system presented points to mechanisms shaping the dynamics of systems in contemporary reality, constituting the environment of a modern organisation. Taking this model into consideration should increase the effectiveness of understanding the mechanisms of system behaviour, while increasing the effectiveness of threat perception, especially in turbulent conditions. In these conditions, it should enable, above all, hypothetical-deductive reasoning and anticipation of the development of a situation (Ćwik, 2017b; Przychocka, 2019; Świerszcz, 2017 and Włodarczyk, 2019).

\section{Concept of a development model of or- ganisational systems}

Distinguishing an elementary unit of the environment of a modern organisation, i.e. an organisational system defined in the previous section, presents a model of an individual element forming the elements of the environment of a modern organisation. The model presented is not static. The author's intention in this section of this paper is to propose a model, although simplified, but presenting a universal model of the development of such systems. The model should allow, at the systemic (general) level, the explanation of phenomena and events occurring or likely to occur in the turbulent environment of a modern organisation. It should also allow the anticipation of the development of events or the consequences of specific events.

The basic assumption of the model is to separate the perception of phenomena, events and related interactions into three autonomous areas: material (physical), mental and intangible. Such a treatment is a kind of reduction of reality aimed at improving analytical processes when perceiving elements of reality. The idea of this type of reduction was found during the analysis of Charles S. Peirce's writing, which talks about three separate universes, he called them the universes of experience, they are objectively existing entities; their symbolic representation and their representation are in the mind (Ćwik, 2017c; pp. 21-37; Ćwik, Świerszcz, 2018 and Janik, 2011, pp. 72-73). Such reduction was also used by other authors and thinkers, such as Plato, who distinguished between the world of matter, the world of spirit and the world of ideas. In the further part of the paper, a concept of perception of reality presented by Karl Raymund Popper will be used, known as the "Three Worlds" theory (Popper, 2002, pp. 191-221). This theory is unrebutted as an approach to perceive reality, which will be used in this paper to present a development model of organisational systems.

According to Popper, the reality that surrounds us can be divided into three worlds, which form ontologically different realities:

World 1 - the physical world: the world of technical systems, plants and living organisms, including matters;

World 2 - the world of psychological states: spiritual, mental and consciousness, encompassing both individual entities and their collectives (collective consciousness);

World 3 - the world of ideas in an objective sense: the world of possible objects of thought, the world of theories in themselves; their logical relations, arguments and problem situations in themselves. It is a world of content and an interpretation of signs, i.e. objective knowledge. It is the world of abstract systems, scientific models

Bogdan ĆWIK, The Journal of Organizational Management Studies, DOI: $10.5171 / 2021.341084$ 
and theories, mathematics and logic, and culture and art. World 3 is an autonomous world whose inhabitants are, for example, Plato's ideas or Socrates's forms or, for example, "sentences in themselves" - Sätze an sich (Bolzano, 1996).

According to Popper, these worlds create a certain "universe" and do not function separately, but interact with each other:

World 1 and World 3 affect World 2;

World 3 affects World 1 through World 2.

\section{Discussion}

Adapting the concept of "Three Worlds" into the field of social sciences, it can be said that "Popper's Worlds" are three interpenetrating environments that can be distinguished in the environment of modern systems of management. At the same time, it can be assumed that in each of these worlds, organisational systems are undergoing the process of development, which has a specific direction and is shaped by specific mechanisms. This development is quantitative and qualitative, and also associated with time and change. Such development is evident in the evolution of matter, in chemical, biological, social, economic and other evolutions. Considering the above arguments, one can put forward the thesis about the "evolution of organisational systems" and claim that as a result of such evolutionary development, a contemporary reality has evolved, where organisational systems, such as modern enterprises, have also developed. Going further, it can be argued that the effect of the evolution of organisational systems is not only in the extraordinary biochemical complexity, but above all, in the complexity and diversity of contemporary reality, visible in the form of constantly developing social, economic, cultural and technological systems. As a result of such reasoning, it can be concluded that the evolution of organisational systems continues in each of Popper's worlds and each of these worlds created an autonomous environment for this evolution, where:
The environment of the evolution of organisational systems in World 1 is inanimate matters (solids, liquids and gases) or the biological environment (collections of plant cells or organisms) - molecular evolution and chemical evolution;

The environment of the evolution of organisational systems in World 2 is the mental and spiritual interior of a human or a group of humans (society, nation, corporation or company) - evolution of the psyche;

The environment of the evolution of organisational systems in World 3 is abstract (immaterial) reality - the evolution of writing, the evolution of culture, the evolution of science and the evolution in economics.

The evolution of organisational systems brings a diversity of quality and an excess of quantity, leading to competition and selection. This can be seen at all levels of this evolution, from bacterial to political, scientific, artistic and religious movements (Buss, 2001; Cairns-Smith, 1996; Coveney, Highfield, 1992; Mumford, 1966; Nazimek, 2001; Nowiński, Batko, 1981; Runciman, 2009; Sahlins, 1960 and Waldrop, 1993).

This evolution is a continuous process of the emergence of increasingly orderly and complex systems. They arise from simpler structures, based on a series of consecutive phases. It is a creative and unique movement that follows the so-called "arrow of time" (Coveney, Highfield, 1992 and Hofkirchner, Schafranek, 2011), which is a consequence of the existence of the logic of general optimisation. The result of the above is the eternal movement; an eternal flow, directed towards increasingly complex forms of systems that are becoming more and more immaterial, increasingly impermanent and increasingly complex. And this does not happen in a deliberate or planned manner, but as a result of energy and flow-related activities implemented in Markov processes (Matalytski, Tikhonen, 2011).

As a result of the above, the development of organisational systems has the character of a growing spiral that runs through the areas of matter, psyche and symbols (abstract

Bogdan ĆWIK, The Journal of Organizational Management Studies, DOI: $10.5171 / 2021.341084$ 
products), simultaneously encompassing complex and comprehensive structures. The development spiral of organisational systems illustrates the transition of these systems to ever higher levels of development, taking into account the various dimensions of this development (Ćwik, 2017a and Ćwik, 2018). According to the concept formulated in this way, it can be concluded that, for example, the market is a product of processes on the development spiral. The development spiral is constantly expanding its circle. The acceleration visible at every step is caused by, for example, the fact that organisational systems are starting to be dominated by intangible flows, encoded in the form of flows of character streams, spreading at the speed made possible by automated electronic media.

\section{Concept of a model of qualitative evolu- tion of organisational systems}

The essence of the concept of the development spiral is the transition to ever higher levels of development, where subsequent levels constitute increasingly complex organisational systems, which are achieved as a result of qualitative changes. Aforementioned considerations will be supplemented by the model of qualitative evolution of systems, developed in 1970 by Valentin Fedorovich Turchin (1977), which can be translated from the original as "Theory of Metasystem Transformation". This model will be adopted to propose a "model of qualitative evolution of organisational systems". In a simplified form, this model can be expressed in Fig. 2.

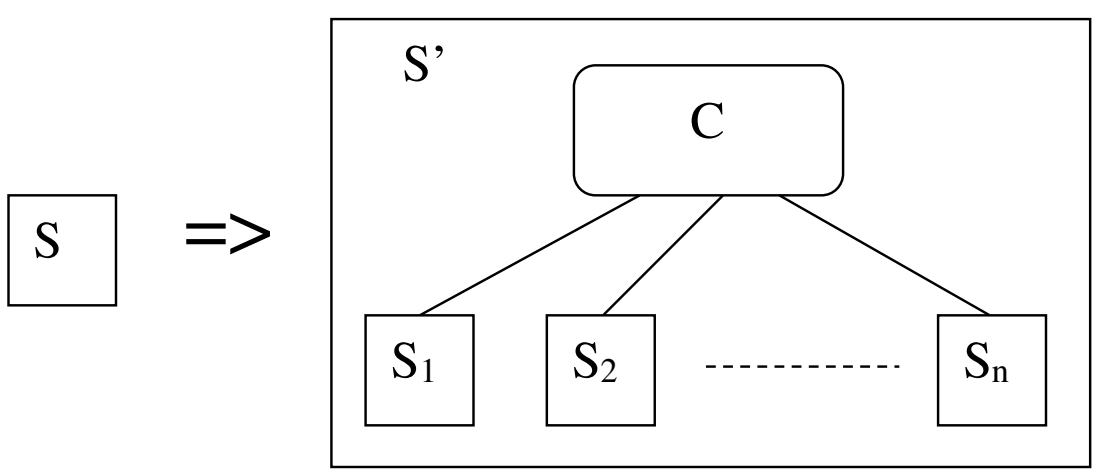

Fig. 2: Model of qualitative evolution of organisational systems

Source: Own study based on (Turchin, 1977, p. 45).

An organisational system $\mathrm{S}$ is presented, with internal mass, energy and information flows. This system has mechanisms to produce its copies, which are created with small variations. These copies constitute a new system $\mathrm{S}^{\prime}$ and become its subsystems (with mass, energy and information streams). To create optimal mass, energy and information flows, each of the subsystems produces transport, energy and information channels to exchange resources with the others as efficiently as possible. It also creates the appropriate structure and allocates some resources for infrastructure. After exceeding a certain level of complexity, to solve growing problems with coordination of activities, system S' produces and develops a control system C. At the same time, individual systems specialise, the transport, energy and information infrastructure is expanded, and the network of relationships in system $S^{\prime}$ thickens. The copies created by system $S$ are subsystems $\mathrm{S}_{1}, \mathrm{~S}_{2}, \ldots \mathrm{S}_{\mathrm{n}}$. Each copy makes subsequent copies, which are made with certain variations. The result is a multi-level structure that requires control and even more complex forms of behaviour. It is essential for a control system that organises information streams to "emerge" from this complexity. In the emerging multi-level control system, each level is associated with a certain activity to form the characteristics for this level. If $\mathrm{A}$ is an activity at a given control level of a certain system, then in the transformation of the organisational system, a new

Bogdan ĆWIK, The Journal of Organizational Management Studies,

DOI: $10.5171 / 2021.341084$ 
activity emerges, which is a new control system. Let's call it activity A'. Controlling activity $A$ creates new activity $A^{\prime}$, which can be expressed as:

$$
\text { Control } \mathrm{A}=\mathrm{A}^{\prime}
$$

A classic example is the qualitative development of a multicellular organism. An example of system $\mathrm{S}$ in such case can be a single cell capable of functioning independently. Cell reproduction processes and their integration creates an organisational system $S^{\prime}$, which is an organism made of millions of cells. At the beginning, the control process, assisting in holding the cells together, is primitive, most often based on the laws of nature, occurring without any separate substructure. But in the subsequent transformation processes of such organisational systems, the cell specialisation appears and the level of complexity increases. One can imagine a situation where several cells cooperate in the exchange of mass, energy and information, and for proper coordination of this cooperation, it becomes necessary for some cells to specialise in the transfer of information.

\section{Discusion}

The model mentioned above probably shows the way of how nerve cells developed, and then others - tissue specialization was born. As a result of these processes, organisms have arisen in which a multilevel hierarchy has developed, in which cells are organized into tissues and tissues into organs and those into organisms, and the whole is controlled by the nervous system. The internal infrastructure has also been created to ensure better functioning of such a system.

It should be emphasised that copying is the most optimal method of creation, because creating something new is always very expensive and time consuming. It is not without reason that devoting a part of resources to maintain structures, as well as to creat mechanisms for copying them, is a common feature of living organisms, and the basic level in Abraham Maslow's hierarchy of needs is physiological (maintenance of existing structures) and safety (protection against negative impacts) needs (Ćwik, 2018).

In such a system, communication and transport processes are organized. An organizational system builds flow and communication infrastructure - the nervous system, vascular systems, and transport and communication networks. In this system, a control (regulatory, management and coordination) system is formed, shaped and separated. It becomes more logical and more advanced - it builds structures, secures its existence and builds infrastructure in a broad sense. It is constantly looking for benefits, establishes cooperation and decides to enter into a conflict if necessary. To convey information to the system, it begins to use strings of characters and look for increasingly sophisticated coding methods, at some stage it undertakes to code energy flows as well as to code the flow of material products.

At subsequent levels, organizational systems replicate and integrate, and hierarchies of beings are created at ever-higher levels.

\section{Conclusion}

The presented models of an organisational system, the model of qualitative evolution of organisational systems, as well as the concept of system development can be useful in interpreting various aspects of reality constituting the external environment of modern organisations. As a result of the qualitative evolution of organisational systems and their quantitative development, continuous creative processes are taking place in this environment, with parallel copying processes, which are slow in biology, lasting millions of years, but much faster in social processes. The evolution of organisational systems continues in all the three worlds of Karl R. Popper. At present, transformation processes have gained such a pace that biological evolution lags behind social evolution, economic evolution, machine evolution and the evolution of character systems. The driving force of evolutionary processes is continuous improvement, searching for the lowest costs and the cheapest solutions. These 
processes result from the presence of the logic of general optimisation of organisational systems. Purposefulness and course of action can be imposed on evolutionary processes at a certain stage, which is only possible when these processes can be controlled. However, at some stage of development, the "control threshold" is exceeded, where complexity causes a return to universal mechanisms, where the resultant of intentional actions of many individuals constitutes a spontaneous, creative, unknown and uncertain action. And the only thing that can be taken into account in anticipating or forecasting in such conditions is the universal perspective of perceiving organisational systems, based on the models mentioned in this study.

It is suggested that the models presented in this study are to be taken into account by managers or employees of managing organizations when they have to take a decision regarding the direction that an unknown or little-known problem related to their current activity may take, in order to manage, plan and outline possible scenarios rationally and effectively. This approach may prove to be crucial for the security of the organization.

\section{References}

- $\quad$ Anderson, P. W., Arrow, K. J. and Pines, D. (1988), The Economy as an Evolving Complex System, Addison-Wesley, Redwood City, CA.

- Arrow K. J., (1971), Essays in the Theory of Risk Bearing, Markham Pub. Co. Apopka, FL.

- Bailey, K. F. (1994), Sociology and the New Systems Theory, University of New York, New York, NY.

- Bergson H., (2004), Creative Evolution, Cosimo Inc., New York, NY.

- Bertalanffy L., (1968), General System Theory: Foundations, Development, Applications,George Braziller, New York NY.

- Bolzano B. (1996),Paradoxes of the Infinite, Yale University Press, New Haven, CT.

- Buckley, W. (1968), Modern Systems Research for the Behavioural Scientist,Aldine, Chicago, IL.
- Buss D.M., (2001), Evolutionary Psychology, Pearson education Limited, Harlow, UK.

- Cairns-Smith A. G., (1996), Evolving the Mind: On the Nature of Matter and the Origin of Consciousness, Cambridge University Press, Cambridge, UK.

- Checkland, P. (1981), Systems Thinking, Systems Practice,John Wiley \& Sons, Chichester, UK.

- Cornell, C. C. and Jude, N. (2015), The Systems Theory of Management in Modern Day Organizations - A Study of Aldgate Congress Resort Limited Port Harcourt. International Journal of Scientific and Research Publications, 5(9).

- Coveney P. and Highfield R. (1992), 'The Arrow of Time: A Voyage through Science to Solve Time's Greatest Mystery', Science and Society, 56 (4), 501-504.

- Ćwik B. (2017a), Postrzeganie sygnałów ostrzegających organizację w sytuacjach niedeterministycznych, WAT, Warszawa, 2017.

- Ćwik, B. (2017b), A Survey on Willingness to Provide Warning Information within A Company during Crisis, Proceedings of the 2017 International Conference on Management Science and Management Innovation (MSMI 2017), 31 , 170-174, doi:10.2991/msmi17.2017.38.

- Ćwik, B. (2017c), 'Multidisciplinary approach to the analysis of the process of perceiving warning signals' Security and Defence Quarterly, 2 (15), 21-37.

- Ćwik B. andŚwierszcz K. (2018), Conception of Warning Signals in Organizational Monitoring Systems, Proceedings of the 31th International Business Information Management Association Conference (IBIMA 2018), ISBN: 978-0-9998551-0-2, 25-26 April 2018, Milan, Italy, Innovation Management and Education Excellence through Vision 2020, Vols I -XI, 61516162.

- Ćwik B. (2018), 'Universal model of perception of contemporary environmental organisations,' Zeszyty Naukowe Politechniki Poznańskiej, 76, 69-86.

- Dawkins, R. (2018), The Selfish Gene, Oxford University Press, Oxford, United Kingdom.

Bogdan ĆWIK, The Journal of Organizational Management Studies, DOI: $10.5171 / 2021.341084$ 
- Forrester, J. W. (1968), Principles of Systems,Wright-Allen Press, Cambridge, MA.

- Hofkirchner W. andSchafranek M. (2011), Philosophy of Complex Systems, Volume 10 in Handbook of the Philosophy of Science.

- Hopej M. andKamiński, R. (2010), Struktury organizacyjne wspólczesnych organizacji, Oficyna Wydawnicza Politechniki Wrocławskiej, Wrocław.

- Janik P., (2011), Koncepcja przekonania w ujęciu semiotyczno-pragmatycznym: Charles S. Peirce, Wydawnictwo WAM, Kraków.

- Lock, I. (2019),'Explicating communicative organization-stakeholder relationships in the digital age: A systematic review and agenda', Public Relations Review,

doi:org/10.1016/j.pubrev.2019.101829

- Makridakis S. andTaleb, N. (2009), 'Living in a world of low levels of predictability,' International Journal of Forecasting, 25(4), 840-844, doi.org/10.1016/j.ijforecast.2009.05.008

- Matalytski M. and Tikhonen O. (2011), Procesy stochastyczne, Akademicka Oficyna Wydawnicza Exit, Warszawa.

- Mumford L., (1966), Technika a cywilizacja. Historia rozwoju maszyny i jej wpływ na cywilizację,PWN Warszawa.

- Nazimek D., (2001), Ewolucja materii, ewolucja środowiska, Wydawnictwo Uniwersytetu Marii Curie-Skłodowskiej, Lublin.

- Nowiński Cz. and Batko B., (1981), Ewolucja biologiczna: związek organizacji i ewolucji, PAN, Instytut Filozofii i Socjologii, Zakład Narodowy im. Ossolińskich, Wrocław.

- Popper K.R., (1972), Objective Knowledge: An Evolutionary Approach, Oxford University Press,Oxford, UK.

- Przychocka I., (2019), Tax Office and Management Control in Polish Reality, Proceedings of the 33th International Business Information Management Association, Conference (IBIMA 2018), 10-11 April 2019, Granada, Spain, 3471-3487, ISBN 978-0-9998551-2-6.

- Radosiński E. andTomczak, S. (2017), 'The effectiveness of discriminant models based on the example of the manufacturing sector,' Operations Research and Decisions, 27(3), 81-97.

- Runciman W.G., (2009), The Theory of Cultural and Social Selection, Cambridge University Press, Cambridge, UK

- Sahlins M.D.,(1960), Evolution and Culture, Univ. of Michigan Press, Ann Arbor, MICH.

- Świerszcz, K. (2017), The Impact of Energy Poverty on the Level of Social Security, Proceedings of the 2017 International Conference on Management Science and Management Innovation (Msmi 2017), 31, 175-178.

- Taylor, W. C., Suminski, R. R., Das, B. M., Paxton, R. J. and Craig, D. W. (2018), Organizational Culture and Implications for Workplace Interventions to Reduce Sitting Time Among Office-Based Workers: A Systematic Review,Frontiers in public health, 6(263). doi:10.3389/fpubh.2018.00263.

- Turchin V.F., (1977), The phenomenon of science, Columbia University Press, New York, NY.

- Waldrop, M. M. (1993), Complexity: The Emerging Science at the Edge of Order and Chaos, Simon \& Schuster Paperbacks, New York, NY.

- Williams, G. C. (19920, Adaptation and Natural Selection. A Critique of Some Current Evolutionary Thought, Princeton University Press, Princeton, New Jersey.

- Włodarczyk E., (2019), Participation as an Element of Effective Safety and Security Promotion at Polish School: Implementation of the Selected Participatory Management Assumptions, Proceedings of the 33th International Business Information Management Association Conference (IBIMA 2018), 10-11 April 2019, Granada, Spain, 3471-3487.

- Wolfram S., (2002), A New Kind of Science, Wolfram Media, Champaign, IL.

Bogdan ĆWIK, The Journal of Organizational Management Studies, DOI: $10.5171 / 2021.341084$ 